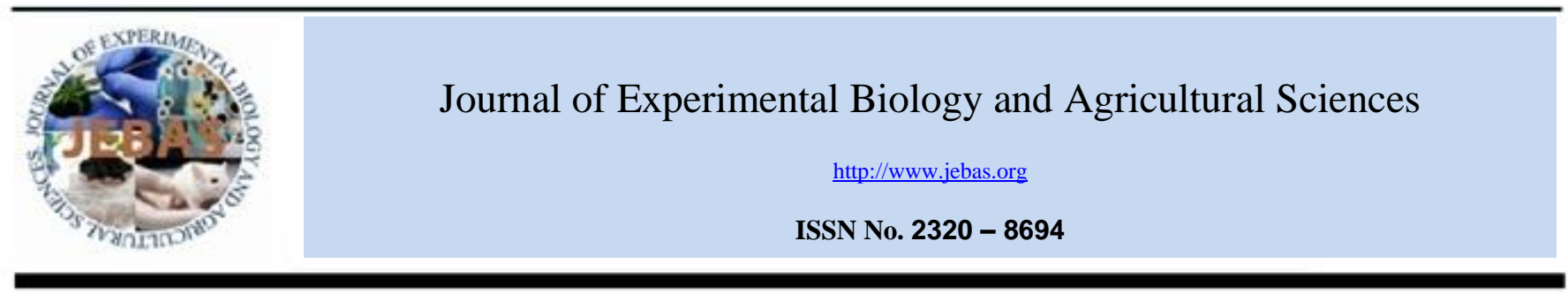

\title{
A WAY OF REPRODUCTIVE MANIPULATION AND BIOLOGY OF Wolbachia pipientis
}

\section{Habib Ali ${ }^{1,2}$,Youming Hou ${ }^{1,2, *}$, Baozhen Tang $^{1,2}$,ZhanghongShi ${ }^{1,2}$, Bin Huang ${ }^{1,2}$, Abrar Muhammad $^{1,2}$ and N B Sanda ${ }^{1,2}$}

${ }^{1}$ Fujian Provincial Key Laboratory of Insect Ecology, Department of Plant Protection, Fujian Agriculture and Forestry University, Fuzhou, 350002 Fujian, China

${ }^{2}$ Key Laboratory of Integrated Pest Management on Crops in Fujian-Taiwan, Ministry of Agriculture, P. R. China, Fuzhou, 350002 Fujian, China

Received - February 11, 2016; Revision - February 28, 2016; Accepted - April 11, 2016

Available Online - April 25, 2016

DOI: http://dx.doi.org/10.18006/2016.4(2).156.168

\section{KEYWORDS \\ Wolbachia \\ Endosymbiotic bacteria \\ Integrated pest management (IPM)}

Coleoptera

\begin{abstract}
The endo-symbiotic relationship between microorganism and eukaryotes are very common and has been broadly investigated from all insect species. The genus Wolbachia are obligatory intracellular bacteria that induce evolutionary alterations and have been frequently reported in egg cytoplasm's of various invertebrates including insects, spiders, mites, scorpions, crustaceans and nematodes, which exert a profound impact on host biology and behavior through a number of phenotypic alternations. Due to its ubiquitous phenotypic behavior, Wolbachia becomes a novel and promising natural micro-biocontrol agent to induce cytoplasmic incompatibility, killing of male embryos, parthenogenesis, and feminization. Autonomous transgenic capability, survival on several host species and the ability to modify the host reproductive systems makes it the most prominent and focusing scientific genomic research from last few decades. The aim of this review is to summarize the significance and recent discoveries of Wolbachia related to various arthropods which lead positive directions to be exploited in future for integrated pest management (IPM) strategies. Further, this review also discussed the biology, phylogeny, distributions, classifications and types of Wolbachia infections on insect orders and coleopterans in particular.
\end{abstract}

* Corresponding author

E-mail: ymhou@fafu.edu.cn (Youming Hou)

Peer review under responsibility of Journal of Experimental Biology and Agricultural Sciences.

Production and Hosting by Horizon Publisher India [HPI] (http://www.horizonpublisherindia.in/).

All rights reserved.
All the article published by Journal of Experimental Biology and Agricultural Sciences is licensed under a Creative Commons Attribution-NonCommercial 4.0 International License Based on a work at www.jebas.org.

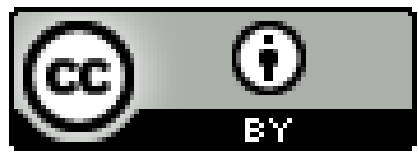




\section{Introduction}

Wolbachia pipientis are maternally inherited gram negative bacteria which becomes a potential endo-symbiotic microbial biocontrol agent (Jeong \& Suh, 2008). It belong to order Rickettsia and are reported in the cytoplasm of various insects (Jeong \& Suh, 2008), terrestrial nematodes (Bourtzis \& Miller, 2003), crustaceans (Cordaux et al., 2012) and Arachnidan (scorpions)(Baradaran et al., 2014; Bryson, 2014). From last few years Wolbachia gained much attention and extensively used against various pest and vector management (Xi \& Dobson, 2005) through manipulating the targeted reproductive system, interference with nutritive and metabolic pathways, distortions the biology of host by various infectious phenotypes like incompatibility of cytoplasm (CI), killing of male embryos, parthenogenesis and feminization (developing the female characters into male)(Anbutsu \& Fukatsu, 2010). These autonomous infectious mechanisms support reproductive phenomenon of the infectious organism and allow the Wolbachia to increase their infection.

Various theoretical and empirical studies suggest that among available alpha-proteobacteria, W. pipientis is more prominent and effective transmitter of intracellular symbiotic infections which known to infect more than $2 / 3$ of global insect communities (Hilgenboecker et al., 2008) ranging from 20 $76 \%$ (Tagami \& Miura, 2004). Moreover, some species of class insecta (lice, Anoplura: Mallophaga) also had 100\% Wolbachia infections (KYEI-POKU et al., 2005).

Wolbachia, not only known as inhibitor of reproductive systems but also known to direct distinguish effect on reduction the diverseness of mtDNA (Galtier et al., 2009), Although, some contradictory views also existed about the effects of Wolbachia and diversity in nuclear material (Telschow et al., 2002), this is because Wolbachia and mtDNA are both transmitted via mother offspring's and hypothesized that reducing the diversity of mtDNA hitches beside as increasing of Wolbachia infections (Armbruster et al., 2003).

Most of the earlier researchers and biologists believed that Wolbachia is maternally inheritable symbionts, i.e. only vertically transfer from egg cytoplasm to offsprings. However recent studies indicate that Wolbachia could also cause infection through horizontal transfer from infected uninfected species (Kawai et al., 2009). It can also be cultured outside the cell (Rasgon et al., 2006) that have great potential to transfer infection and live outside the host cell (culture cell) over a reasonable period of time (Dobson et al., 2002b).This discovery of in vitro production of Wolbachia leads researcher towards positive direction and not only open the doors of IPM programs in agriculture sector but also help to control the insect vector of various human disease i.e. Dengue, Chikungunya, and Plasmodium (Moreira et al., 2009)

Over the last few decades, Wolbachia-arthropods association becomes a focusing research point and attract intense fascination of researchers and genomic scientists due to its multiple behaviors, diverse host range, potential for rapid host speciation and have a great ability to alter host embryonic progress and mitotic developments (Lassy \& Karr, 1996). It has also great potential to control the population of insect's pests as a microbial natural enemy with multiple ways of infectious phenotypes to manipulate host biology of targeted populations. Due to its ubiquitous behaviors, evolutionary, biologically and ecologically it has become a key potential intracellular biocontrol agent in pest biocontrol strategies. This review highlights and evaluates updated genetical, biological and ecological role of Wolbachia in various insect orders which can be used as the potential role in future integrated pest management (IPM) strategies.

\section{Taxonomic characteristics of the Wolbachia}

Wolbachia species are members of the obligate intracellular Rickettsiales and forge as a dual competitive microbial agent (DCMA) like parasitic relationships with numbers of arthropods and mutualistic relationships with various insect orders, particularly with nematodes. During their 100-millionyear interaction with their hosts, the cytoplasmic transmitted bacteria have evolved as "reproductive parasites which belongs to Class: Alpha-proteobacteria, order Rickettsiales and Family Rickettsiaceae, firstly reported by entomologist, Marshall Herting and Samuel Wolbach in 1924 from sex cells of Culex pipiens Linnaeus (mosquito)(Hertig \& Wolbach, 1924). However, comprehensive publication was done in 1936 (Hertig, 1936).

\section{Phylogeny and Classification of Wolbachia}

Among the family Anaplasmataceae, Wolbachiais is well known for its capacity to alter the reproductive developments of host (ovaries and testes). It is considered as most common endosymbiotic bacteria that infect millions of insect species from all around the globe (Jeyaprakash \& Hoy, 2000; Hilgenboecker et al., 2008). Within the class of alphaproteobacteria, Wolbachia also has members such as Anaplasma, Ehrlichia, Neorickettsia which are genetically much-closed genera to Wolbachia (Figure 1 (a)).

On the basis of sequence information obtained with targeted bacterial genes includes16S rDNA (partial small subunit ribosomal DNA, groEl (heat shock protein gene), wsp (outer surface coat protein gene) (Baldo et al., 2006; Paraskevopoulos et al., 2006) and ftsZ (cell division gene), Wolbachia infections have been characterized and divided into eight super groups AH (Zhou et al.,1998; Bordenstein et al., 2009; Ros et al., 2009) Moreover, some recent literature reported that infectious strains of Wolbachia can further be classified into 3 more super groups, that's A-K super orders (Zhou et al.,1998; Bordenstein et al., 2009; Ros et al., 2009; Salunke et al., 2010) as shown in Figure b (1): Table. 1. 

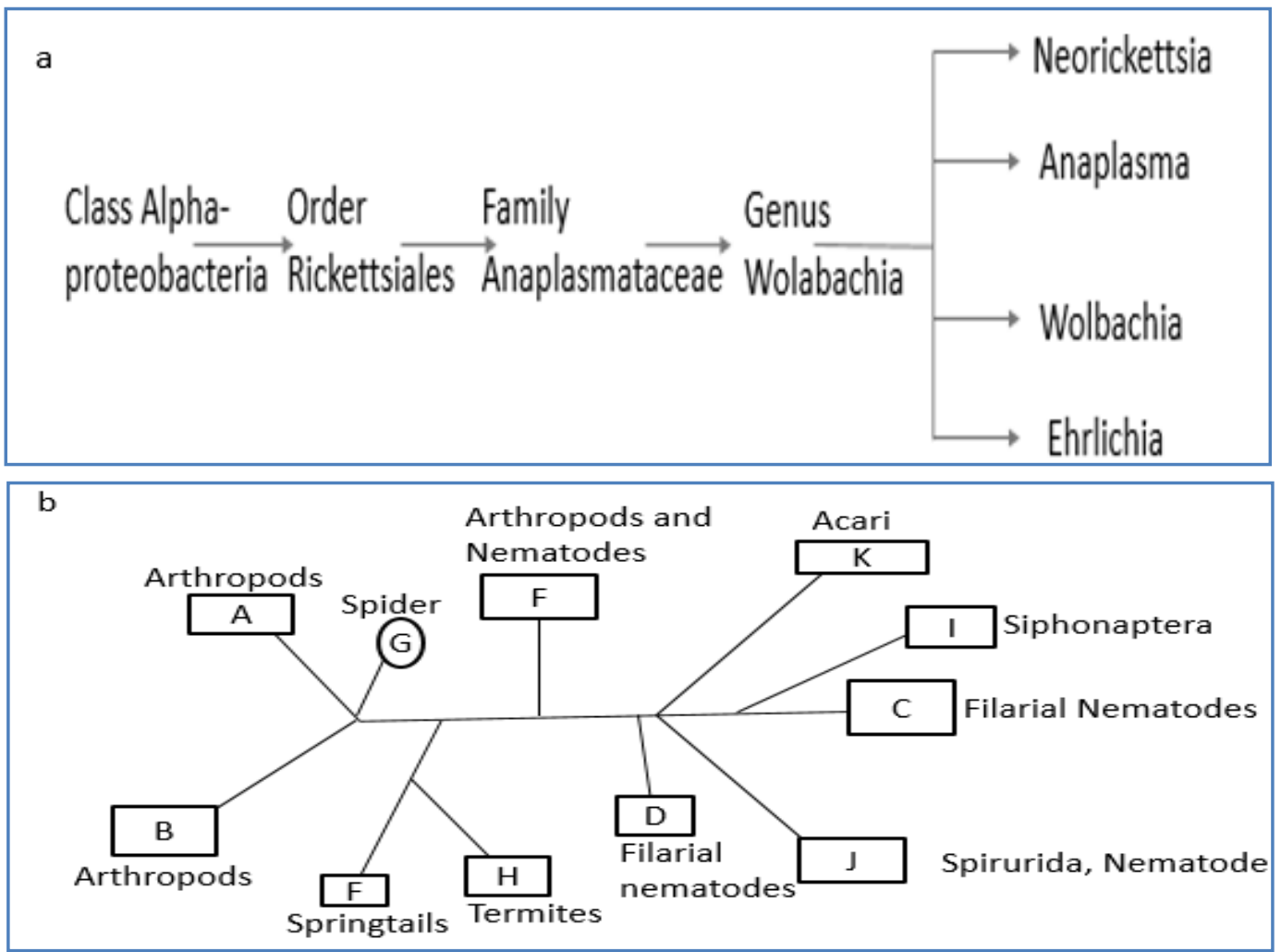

Figure 1 (a) Division of Wolbachia with genetically closed genera within class alpha-proteobacteria: (b) Division of Wolbachia strain into 11 super groups within different host species.

4 Identification and detection of Wolbachia

Wolbachia is completely dependent on the cytoplasmic atmosphere of the host. The average size of these bacteria is ranging from 0.8 to $1.5 \mu \mathrm{m}$ (Herting et al., 1936) and covers by at least 2 cell membrane. Although these bacteria have been identified as maternally inherited infection through infected mother to offspring's but the infections of Wolbachia is not only limited to reproductive systems of the host but it also infect and colonized in various tissues such as muscle cell, digestive organs, brain, fat body and hemolymph of the host (Min \& Benzer, 1997; Cheng \& Aksoy, 1999; Dobson et al., 1999; Cheng et al., 2000; Serbus et al., 2008; Albertson et al., 2009). Infection of Wolbachia can be confirmed within the tissues of various invertebrates by using various identification techniques such as visualized Giemsa stain (Hering et al., 1936), fluorescent dye DAPI, fluorescent cells nucleic acids dye SYTO 11 techniques (Albertson et al., 2009). Furthermore, in situ hybridization with specific Wolbachia DNA probes and staining of immune through antibodies (Moreira et al., 2009) is also used for the diagnosing the Wolbachia infection inside the host tissues. A very sensitive PCR (Polymerase chain reaction) technique along with other tools like Hybridization of DNA and analysis of sequence are also extensively used for Wolbachia detection.

Table 1 Division of Wolbachia infections into 11 supergroups

\begin{tabular}{|lll|}
\hline Super-groups & Host name & References index \\
\hline A, B, E & Arthropods & (Vandekerckhove et al., 1999; Lo et al., 2002; Lo et al., 2007) \\
\hline C, D & Filarial Nematodes & (Lo et al., 2007) \\
\hline F & Both Arthropods and Nematodes & (Campbell et al., 1992; Rasgon \& Scott, 2004) \\
\hline G & Spiders & (Goodacre et al., 2006) \\
\hline H & Termites & (Bordenstein et al., 2009) \\
\hline I & Siphonaptera & (Ros et al., 2009) \\
\hline J & Spirurida, Nematoda & (Ros et al., 2009) \\
\hline \hline K & Prostigmata, Acarina & (Ros et al., 2009) \\
\hline
\end{tabular}


Table 2 Killing of male embryo discovered into following host species.

\begin{tabular}{|ll|}
\hline Host name & References \\
\hline Coleoptera & (Majerus \& Zakharov, 2000) \\
\hline Diptera & (Dyer \& Jaenike, 2004) \\
\hline Lepidoptera & (Jiggins et al., 1998; Jiggins et al., 2000; Fujii et al., 2001; Jiggins et al., 2001) \\
\hline \hline Class Arachnida & (Zeh et al., 2005; Koop et al., 2009) \\
\hline
\end{tabular}

\section{Wolbachia-host association}

The endosymbiont Wolbachia manipulate and alter the host reproductive systems (Werren et al., 2008) through various phenotypic mechanisms such as the killing of male sperm, feminization, cytoplasmic incompatibility and parthenogenesis. All phenotypes are focus on the enhancing the progenies of infected female of associated host population and therefore, may cause the reason to increase the transmission and availability of bacteria within the hosts. These effects may be beneficial or detrimental, and are confounded by genetic and environmental factors. Our focus is to enlighten the hostinteractions with most recent investigation related to insect communities by following phenotypic behaviors.

\subsection{Killing of male embryos}

Wolbachia is one of several types of maternally-inherited bacteria that kill males during embryonic development (Stevens et al., 2001) and significantly reduced the populations of males. Hence, infected females may lay a mixed brood of male and female eggs, but only female eggs survive to become adults. A broad range of endosymbionts like Flavobacteria, Rickettsia, Arsenophonus, Wolbachia, and Spiroplasma are associated with the host and responsible for induction of male killing (Anbutsu \& Fukatsu, 2010)but cytological mechanisms causing male-killing are still unknown (Hornett et al., 2006; Sheeley \& McAllister, 2009). Killing of a male reported in class Insecta including Lepidoptera, Diptera and Coleoptera and class Arachnidan (Table 2).

\subsection{Feminization}

Feminizing strains of Wolbachia make changes in genetic of male hosts and force it to develop into functional female which is known as alteration of sex or feminization. Such infections are common in terrestrial isopods especially in woodlouse, Armadillidium vulgare have been best studied (Rousset et al.,
1992; Cordaux et al., 2012). Sex in these crustaceans is determined by the action of a male hormone that suppresses female development. Wolbachia is thought to inhibit development of the androgenic gland that produces this hormone and also may block receptor sites required for hormone activity. It is one of the most advantageous mechanisms of Wolbachia in which double offspring of the female which eventually increase the rate of infections. So far, the limits of Wolbachia distribution via feminization have been discovered only in three orders of class Insecta (Table 3) and yet needs to be determined more.

\subsection{Cytoplasmic incompatibility}

Cytoplasmic incompatibility (CI) is the most abundant Wolbachia induced phenomena that alter the host reproduction.The presence of CI in Wolbachia have been frequently reported in wide range of insects includes flour beetles, alfalfa weevils, wasps, plant hoppers, fruit flies, flour moths, wood louse, mites and numerous mosquitoes species.

CI may occurred by matting's between Wolbachia infected males and uninfected females, or between any partners infected with different strains of Wolbachia. However, CI occurs in two directions; when Wolbachia-infected male cross with uninfected female causing unidirectional CI. Secondly when both male and female carry opposite strains which are contrastive to each other known as bidirectional CI (Telschow et al., 2005; Merçot \& Poinsot, 2009). These types of CI caused higher embryonic death and organism produced less number of progenies (Breeuwer \& Werren, 1990; O'Neill \& Karr, 1990; Bourtzis \& O'Neill, 1998; Breeuwer \& Werren, 2007; Bourtzis \& Miller, 2014). Recently Tram et al. (2003) reported the occurrence of Wolbachia in male sperm and found that it introduces a factor here that prevents embryogenesis in the fertilized egg, unless the female partner is infected with the same Wolbachia strain to allow the sperm's 'rescue'.

Table3 Feminization identified into different hosts.

\begin{tabular}{|ll|}
\hline Host name & References \\
\hline Lepidoptera & (Hiroki et al., 2002; Kageyama et al., 2002; Narita et al., 2007) \\
\hline Hemiptera & (Negri et al., 2006) \\
\hline \hline Terrestrial Isopods & (Verne et al., 2007; Bouchon et al., 2008) \\
\hline
\end{tabular}


Table 4 Cytoplasmic incompatibility identified into different host.

\begin{tabular}{ll}
\hline Host name & References \\
\hline Coleoptera & (Stevens \& Wade, 1990) \\
\hline Diptera & (Yamada et al., 2011; Zheng et al., 2011) \\
\hline Isopods & (Moret et al., 2001) \\
\hline Acari & (Zhang et al., 2015) \\
\hline Lepidoptera & (Brower, 1976; Kellen et al., 1981) \\
\hline Hymenoptera & (Reed \& Werren, 1995) \\
\hline \hline Homoptera & (Noda, 1987) \\
\hline
\end{tabular}

Table 5 Discoveries of induction of parthenogenesis into different host.

\begin{tabular}{|ll|}
\hline Host name & References \\
\hline Thysanoptera & (Arakaki et al., 2001) \\
\hline Acari & (Husseneder \& Collier, 2009) \\
\hline \hline Hymenoptera & (Pannebakker et al., 2005) \\
\hline
\end{tabular}

Unidirectional CI is most frequent and usually occurs between males infected with a single strain or female without any strain of Wolbachia. While the bidirectional CI have been reported only in the condition when both partners are infected with the same Wolbachia strains. The reason of wide spreading this phenotype because of two elements responsible for two different Wolbachia antagonistic functions (Werren, 1997; Poinsot et al., 2003) known as modification and rescue. Like other phenomena, CI also have limited investigations in various Wolbachia associated hosts (Yamada et al., 2007). Therefore it is necessary to investigate this phenotype in all insect communities. The most recent discoveries of $\mathrm{Cl}$ induced by Wolbachia are given below in Table 4 .

\subsection{Induction of parthenogenesis}

Wolbachia also associated with parthenogenesis induction (PI) in different host species. Offspring's of these insects have three different types of sex determination i.e. diploid male and female (diplodiploidy); haploid male and diploid female (haplodiploidy); diploid female without a male (thelytoky) (Normark, 2003). Wolbachia increases the targeted infected female offspring by second type (haplodiploid) of sex determination in various insect species. PI bacteria are found in both A and B divisions of Wolbachia, and phylogenetic evidence suggests that PI has evolved several times independently in these bacteria. It therefore appears that PI can evolve easily in the Wolbachia. Still lot of work needs to be done to determine, how PI Wolbachia cause gamete duplications, disruption of the centrosome or spindle formation, attachment of the spindle to the chromosomes, or spindle kinetics. So far, reported discoveries of Wolbachia via PI in various arthropods are discussed below in Table 5.

\section{Parasitic role of Wolbachia}

Wolbachia (Rickettsiales: Rickettsiaceae) are one of most active maternally inherited endosymbiotic proteobacteria that inhabit wide range of arthropods and nematodes to manipulate their reproductive systems. Parasitic behavior of intercellular bacteria with invertebrates are very common and play an important role to manipulate host biological interactions such as reproductions, developments, gene expression (Zhao et al., 2013) and immune systems (Ivanov \& Littman, 2011). A bulk of researches have been conducted to identified the insectbacteria association particularly Wolbachia exerts negative impacts to reduce host fitness, responsible for degradation and early death (Min \& Benzer, 1997), responsible for pathogen dissemination (Cook et al., 2008), reduce host survival rate (McMeniman et al., 2009), manipulate reproductive system (McGraw et al., 2001) and inhibit the pathogenicity of host (Walker et al., 2011).With these above reproductive manipulations, the bacterium (Wolbcahia) thrives in its various hosts at the expense of the hosts' reproduction and act like reproductive parasite to reduced host populations successfully.

7 Mutualistic role of Wolbachia

Endo-symbiotic microorganism, particularly Wolbachia are not only played an important role in manipulating of host reproduction but also provide protection against targeted host pathogens (Moran et al., 2008; Gross et al., 2009; Cook \& McGraw, 2010). It is beneficial for the host species (Taylor et al., 2013) by increasing the survival rate of host or insect species (Vala et al., 2003; Dobson et al., 2004; Foster et al., 2005; Weeks et al., 2007; Zhao et al., 2013) or enhancing the fecundity rate (Girin \& Bouletreau, 1995; Dobson et al., 2002a; Fry et al., 2004; Xie et al., 2011). In Tribolium confusum (Coleoptera: Tenebrionidae) infected male sperm with Wolbachia takes long reproductive time than compared to uninfected ones. Infection may also result to protect the host by suppressing the harmful genes (Drosophila melanogaster) (Starr \& Cline, 2002; Clark et al., 2005). Moreover in Tetranychus urticae, Wolbachia also causes interference in the metabolism of iron which decreases oxidative stress and reduces the death of cells, eventually, enhance the chance of 
reproduction within the host (Kremer et al., 2009). Another mutualistic example of Wolbachia is in wasp, Asobara tabida (Dedeine et al., 2005) here it is very essential for embryogenesis, it also play a hypothesised role in ferritin expression (Kremer et al., 2009; Kremer et al., 2012), in fruits flies, D. melanogaster, D. simulans it caused resistance against viral RNA infection (Hedges et al., 2008; Teixeira et al., 2008; Osborne et al., 2009), in mosquitoes, Aedes aegpti it activate the immune systems against numerous pathogens (Moreira et al., 2009; Bian et al., 2010; Van den Hurk et al., 2012) and are also responsible for the microRNAs expressions (Hussain et al., 2011).

8 Wolbachia discoveries in Order Coleoptera
Order Coleoptera economically and ecologically recognized has a big and successful order cover almost $1 / 4$ of all known animals species (Hunt et al., 2007). The intercellular relationships with microorganism are very common and frequently investigated in many species of arthropods. Some endosymbionts are very important and play a significant role in development and survival of the various hosts. Last few decades members of class alpha-proteobacteria particularly Wolbachia are widely identified in numerous species of order Coleoptera and more than thirty (30) beetle species have been discovered in this intracellular bacteria so far (Lachowska et al., 2010) and all belong to supergroups A and B, except Rhinocyllus conicus (Froehlich) which belongs to supergroup F (Lo et al., 2002) (Table 6).

Table 6 Wolbachia discoveries in coleopteran species.

\begin{tabular}{|c|c|c|c|}
\hline Common name of weevil & Scientific name & Family & References \\
\hline Azuki bean beetle & Callosobruchus Chinensis & Bruchidae & (Kondo et al., 1999) \\
\hline Vine weevil & Otiorhynchus sulcatus & Curculionidae & (Son et al., 2008) \\
\hline Ladybird beetle & Adalia bipunctata $L$. & Coccinellidae & (Sokolova et al., 2002; Elnagdy et al., 2013) \\
\hline Two spotted Ladybug & Adalia bipunctata & Coccinellidae & (Hurst et al., 1992) \\
\hline Flour beetle & Tribolium confusum & Tenebrionidae & (Wade \& Stevens, 1985) \\
\hline Black flour beetle & Tribolium madens & Tenebrionidae & (Fialho \& Stevens, 2000) \\
\hline Bark beetle & Pityogenes chalcographus & Scolytinae & (Wolfgang et al., 2009) \\
\hline Rice water weevil & Lissorhoptrus oryzophilus Kuschel & Curculionidae & (Chen et al., 2012) \\
\hline Raspberry beetle & Byturus tomentosus & Byturidae & (Malloch et al., 2000) \\
\hline Tribe naupactini & & Curculionidae & (Rodriguero et al., 2010) \\
\hline Alnus ambrosia beetle & Xylosandrus germanus & Curculionidae & (Kawasaki et al., 2010) \\
\hline Northern Corn rootworm & Diabrotica barberi & Chrysomelidae & (Roehrdanz \& Levine, 2007) \\
\hline Bean beetles & Callosobruchus Chinensis & Chrysomelidae/ Bruchinae & (Kondo et al., 2011) \\
\hline Cabbage Seedpod weevil & Ceutorhynchus obstrictus & Curculionidae & (Floate et al., 2011) \\
\hline Coffee berry borer & Hypothenemus hampei & Scolytidae & (Vega et al., 2002) \\
\hline Alfalfa weevil & Hypera postica & Curculionidae & (Klostermeyer, 1978; Hsiao \& Hsiao, 1984) \\
\hline Western corn rootworm & Diabrotica virgifera virgifera & Chrysomelidae & (Giordano et al., 1997; Barr et al., 2010) \\
\hline Mexican corn rootworm & Diabrotica virgiferazeae & Chrysomelidae & (Giordano et al., 1997) \\
\hline $\begin{array}{l}\text { Northern } \\
\text { corn rootworm }\end{array}$ & Diabrotica barberi & Chrysomelidae & (Roehrdanz \& Levine, 2007) \\
\hline Rice weevil & Sitophilus oryzae & Curculionidae & (Giordano et al., 1997) \\
\hline Korean endemic firefly & Luciola unmunsana & Lampyridae & (Jeong et al., 2009) \\
\hline Rice water weevil & Lissorhoptrus oryzophilus & Curculionidae & $\begin{array}{l}\text { (Saito et al., 2005; Chen et al., 2012; Lu et } \\
\text { al., 2013) }\end{array}$ \\
\hline Flea beetle & Aphthona nigriscutis & Chrysomelidae & (Roehrdanz et al., 2006) \\
\hline Tobacco beetle & Lasioderma serricorne (Fabricius) & Anobiidae & (Kageyama et al., 2010) \\
\hline Bread beetle or biscuit beetle & Stegobium paniceum (Linnaeus) & Anobiidae & (Kageyama et al., 2010) \\
\hline Grain beetle & Oryzaephilus surinamensis (Linnaeus & Silvanidae & (Kageyama et al., 2010) \\
\hline Cowpea weevil & Callosobruchus analis (Fabricius) & Bruchidae & (Kageyama et al., 2010) \\
\hline Cabinet beetle & Anthrenus verbasci (Linnaeus & Dermestidae & (Kageyama et al., 2010) \\
\hline Confused flour beetle & Tribolium confusum & Tenebrionidae & (Ming et al., 2015) \\
\hline
\end{tabular}




\section{Conclusions}

Wolbachia belongs to a diverse group of endosymbiotic bacteria which can manipulate the reproductive development of numerous arthropods. Tremendous achievements have been made from last few decades to understand the biology and mechanism of Wolbachia, specifically in the field of genetics and molecular biology through a numbers of advanced Wolbachia research tools and technologies. Now a days Wolbachia has become a potential biocontrol agent due to its various infectious phenotypic behaviors including incompatibility of cytoplasm, killing of the male embryo and induction of parthenogenesis and feminization which can change the biology of the host. Theoretical and experimental analysis show that Wolbachia may greatly affect the population of host species and efficiently used as a biocontrol agent in pest management strategies. Main purpose of this review is to highlight the significances and current discoveries of Wolbachia in various arthropods that lead a possible positive role in the field of IPM programs but still needs lot of key questions to be addressed like" can Wolbachia broadly used as biocontrol agent? On what conditions it behave like parasitic or mutualistic? Exact phenomena of this intracellular bacterium to manipulate host reproductions? Great attention is likely to be made to answering of these questions and next few years of Wolbachia studies therefore promises to be an exciting one.

\section{Acknowledgement}

We are very grateful for the grant from the National Natural Science Foundation of China (31470656).

\section{Conflict of interest}

Authors would hereby like to declare that there is no conflict of interests that could possibly arise.

\section{References}

Albertson R, Casper-Lindley C, Cao J, Tram U, Sullivan W (2009) Symmetric and asymmetric mitotic segregation patterns influence Wolbachia distribution in host somatic tissue. Journal of cell science 122:4570-4583.

Anbutsu H, Fukatsu T (2010) Evasion, suppression and tolerance of Drosophila innate immunity by a male-killing Spiroplasma endosymbiont. Insect molecular biology 19: 481488.

Arakaki N, Miyoshi T, Noda H (2001)Wolbachia-mediated parthenogenesis in the predatory thrips Franklinothrips vespiformis (Thysanoptera: Insecta). Proceedings of the Royal Society of London B: Biological Sciences 268:1011-1016.

Armbruster P, Damsky WE, Giordano R, Birungi J, Munstermann LE, Conn JE (2003) Infection of New-and OldWorld Aedes albopictus (Diptera: Culicidae) by the intracellular parasite Wolbachia: implications for host mitochondrial DNA evolution. Journal of Medical Entomology 40:356-360.

Baldo L, Hotopp JC, Jolley KA, Bordenstein SR, Biber SA, Choudhury RR, Hayashi C, Maiden MC, Tettelin H, Werren $\mathrm{JH}$ (2006) Multilocus sequence typing system for the endosymbiont Wolbachia pipientis. Applied and Environmental Microbiology 72:7098-110.

Baradaran M, Jalali A, Jolodar A (2014) Molecular diagnosis of Wolbachia endosymbiont from Iranian scorpion Hemiscorpius lepturus using polymerase chain reaction (PCR) amplification of $16 \mathrm{~S}$ rDNA gene. African Journal of Biotechnology 10:19802-19206.

Barr KL, Hearne LB, Briesacher S, Clark TL, Davis GE (2010) Microbial symbionts in insects influence down-regulation of defense genes in maize. PloS one 5:e11339.

Bian G, Xu Y, Lu P, Xie Y, Xi Z (2010) The endosymbiotic bacterium Wolbachia induces resistance to dengue virus in Aedes aegypti. PLoS pathogens 6:e1000833.

Bordenstein SR, Werren JH (2007) Bidirectional incompatibility among divergent Wolbachia and incompatibility level differences among closely related Wolbachia in Nasonia. Heredity 99:278-287.

Bordenstein SR, Paraskevopoulos C, Hotopp JC, Sapountzis P, Lo N, Bandi C, Tettelin H, Werren JH, Bourtzis K (2009) Parasitism and mutualism in Wolbachia: what the phylogenomic trees can and cannot say. Molecular Biology and Evolution 26:231-41.

Bouchon D, Cordaux R, Grève P (2008) Feminizing Wolbachia and the evolution of sex determination in isopods. Insect Symbiosis 3:273-294.

Bourtzis K, Miller TA (2003) Insect symbiosis. CRC Press.

Bourtzis K, Miller TA (2014) Insect symbiosis. CRC Press.

Bourtzis K, O'Neill S (1998) "Wolbachia" Infections and Arthropod Reproduction. Bioscience 48:287-293.

Breeuwer JA, Werren JH (1990) Microorganisms associated with chromosome destruction and reproductive isolation between two insect species. Nature 346: 558-560.

Brower JH (1976) Cytoplasmic Incompatibility: Occurrence in a Stored-product Pest Ephestia cautella1. Annals of the Entomological Society of America 69:1011-1015.

Bryson RW (2014) Bacterial endosymbiont infections in 'living fossils': a case study of North American vaejovid scorpions. Molecular Ecology Resources 14:789-793. 
Campbell BC, Bragg TS, Turner CE (1992) Phylogeny of symbiotic bacteria of four weevil species (Coleoptera: Curculionidae) based on analysis of $16 \mathrm{~S}$ ribosomal DNA. Insect Biochemistry and Molecular Biology 22:415-421.

Chen SJ, Lu F, Cheng JA, Jiang MX, Way MO (2012) Identification and biological role of the endosymbionts Wolbachia in rice water weevil (Coleoptera: Curculionidae). Environmental Entomology 41:469-477.

Cheng Q, Aksoy S (1999) Tissue tropism, transmission and expression of foreign genes in vivo in midgut symbionts of tsetse flies. Insect Molecular Biology 8:125-132.

Cheng Q, Ruel T, Zhou W, Moloo S, Majiwa P, O'neill S, Aksoy S (2000) Tissue distribution and prevalence of Wolbachia infections in tsetse flies, Glossina spp. Medical and Veterinary Entomology 14:44-50.

Clark ME, Anderson CL, Cande J, Karr TL (2005) Widespread prevalence of Wolbachia in laboratory stocks and the implications for Drosophila research. Genetics 170:1667-1675.

Cook PE, McGraw EA (2010) Wolbachia pipientis: an expanding bag of tricks to explore for disease control. Trends in parasitology 26:373-375.

Cook PE, McMeniman CJ, O’Neill SL (2008) Modifying insect population age structure to control vector-borne disease. Transgenesis and the management of vector-borne disease, Springer publication, Pp. 126-140.

Cordaux R, Pichon S, Hatira HBA, Doublet V, Grève P, Marcadé I, Braquart-Varnier, C, Souty-Grosset C, CharfiCheikhrouha F, Bouchon D (2012) Widespread Wolbachia infection in terrestrial isopods and other crustaceans. Zookeys, 176: 123.

Dedeine F, Bouletreau M, Vavre F (2005)Wolbachia requirement for oogenesis: occurrence within the genus Asobara (Hymenoptera, Braconidae) and evidence for intraspecific variation in A. tabida. Heredity 95:394-400.

Dobson S, Rattanadechakul W, Marsland E (2004) Fitness advantage and cytoplasmic incompatibility in Wolbachia single-and superinfected Aedes albopictus. Heredity 93:135142.

Dobson SL, Bourtzis K, Braig HR, Jones BF, Zhou W, Rousset F, O'Neill SL (1999) Wolbachia infections are distributed throughout insect somatic and germ line tissues. Insect Biochemistry and Molecular Biology 29:153-160.

Dobson SL, Marsland EJ, Rattanadechakul W (2002a) Mutualistic Wolbachia infection in Aedes albopictus: accelerating cytoplasmic drive. Genetics 160:1087-1094.
Dobson SL, Marsland EJ, Veneti Z, Bourtzis K, O'Neill SL (2002b) Characterization of Wolbachia host cell range via the in vitro establishment of infections. Applied and Environmental Microbiology 68:656-660.

Dyer KA, Jaenike J (2004) Evolutionarily Stable Infection by a Male-Killing Endosymbiont in Drosophila innubila Molecular Evidence From the Host and Parasite Genomes. Genetics 168:1443-1455.

Elnagdy S, Majerus M, Gardener M, Lawson HLJ (2013) The direct effects of male killer infection on fitness of ladybird hosts (Coleoptera: Coccinellidae). Journal of Evolutionary Biology 26:1816-1825.

Fialho RF, Stevens L (2000) Male-killing Wolbachia in a flour beetle. Proceedings of the Royal Society of London. Series B: Biological Sciences 267:1469-1473.

Floate KD, Coghlin PC, Dosdall L (2011) A Test Using Wolbachia Bacteria to Identify Eurasian Source Populations of Cabbage Seedpod Weevil, Ceutorhynchus obstrictus (Marsham), in North America. Environmental Entomology 40:818-823.

Foster J, Ganatra M, Kamal I, Ware J, Makarova K, Ivanova N, Bhattacharyya A, Kapatral V, Kumar S, Posfai J (2005) The Wolbachia genome of Brugia malayi: endosymbiont evolution within a human pathogenic nematode. PLoS Biology 3:e121.

Fry A, Palmer M, Rand D (2004) Variable fitness effects of Wolbachia infection in Drosophila melanogaster. Heredity 93:379-389.

Fujii Y, Kageyama D, Hoshizaki S, Ishikawa H, Sasaki T (2001) Transfection of Wolbachia in Lepidoptera: the feminizer of the adzuki bean borer Ostrinia scapulalis causes male killing in the Mediterranean flour moth Ephestia kuehniella. Proceedings of the Royal Society of London. Series B: Biological Sciences 268:855-859.

Galtier N, Nabholz B, Glémin S, Hurst G (2009) Mitochondrial DNA as a marker of molecular diversity: a reappraisal. Molecular Ecology 18:4541-4550.

Giordano R, Jackson JJ, Robertson HM (1997) The role of Wolbachia bacteria in reproductive incompatibilities and hybrid zones of Diabrotica beetles and Gryllus crickets. Proceedings of the National Academy of Sciences 94:1143911444.

Girin C, Bouletreau M (1995) Microorganism-associated variation in host infestation efficiency in a parasitoid wasp, Trichogramma bourarachae (Hymenoptera: Trichogrammatidae). Experientia 51:398-401. 
Goodacre SL, Martin OY, Thomas CG, Hewitt GM (2006) Wolbachia and other endosymbiont infections in spiders. Molecular Ecology 15:517-527.

Gross R, Vavre F, Heddi A, Hurst GD, Zchori-Fein E, Bourtzis K (2009) Immunity and symbiosis. Molecular Microbiology 73:751-759.

Hedges LM, Brownlie JC, O'Neill SL, Johnson KN (2008)Wolbachia and virus protection in insects. Science 322:702-702.

Hertig M (1936) The rickettsia, Wolbachia pipientis (gen. et sp. n.) and associated inclusions of the mosquito, Culex pipiens. Parasitology 28:453-486.

Hertig M, Wolbach SB (1924) Studies on rickettsia-like microorganisms in insects. The Journal of Medical Research 44:P 329.

Hilgenboecker K, Hammerstein P, Schlattmann P, Telschow A, Werren JH (2008) How many species are infected with Wolbachia?-a statistical analysis of current data. FEMS Microbiology Letters 281:215-220.

Hiroki M, Kato Y, Kamito T, Miura K (2002) Feminization of genetic males by a symbiotic bacterium in a butterfly, Eurema hecabe (Lepidoptera: Pieridae). Naturwissenschaften 89:167170 .

Hornett EA, Charlat S, Duplouy AM, Davies N, Roderick GK, Wedell N, Hurst GD (2006) Evolution of male-killer suppression in a natural population. PLoS biology 4: e283

Hsiao C, Hsiao T (1984) Cytogenetic studies of alfalfa weevil (Hypera postica) strains (Coleoptera: Curculionidae). Canadian Journal of Genetics and Cytology 26:348-353.

Hunt T, Bergsten J, Levkanicova Z, Papadopoulou A, John OS, Wild R, Hammond PM, Ahrens D, Balke M, Caterino MS (2007) A comprehensive phylogeny of beetles reveals the evolutionary origins of a superradiation. Science 318:19131916.

Hurst GDD, Majerus MEN, Walker LE (1992) Cytoplasmic male killing elements in Adalia bipunctata(Linnaeus)(Coleoptera: Coccinellidae). Heredity 69:84-91.

Hussain M, Frentiu FD, Moreira LA, O'Neill SL, Asgari S (2011)Wolbachia uses host microRNAs to manipulate host gene expression and facilitate colonization of the dengue vector Aedes aegypti. Proceedings of the National Academy of Sciences 108:9250-9255

Husseneder C, Collier RE (2009) Paratransgenesis in termites. Insect Symbiosis 3:361-376.
Ivanov II, Littman DR (2011) Modulation of immune homeostasis by commensal bacteria. Current Opinion in Microbiology 14:106-114.

Jeong G, Kang T, Park H, Choi J, Hwang S, Kim W, Choi Y, Lee K, Park I, Sim H (2009) Wolbachia infection in the Korean endemic firefly, Luciola unmunsana (Coleoptera: Lampyridae). Journal of Asia-Pacific Entomology 12:33-36.

Jeyaprakash A, Hoy M (2000) Long PCR improves Wolbachia DNA amplification: wsp sequences found in $76 \%$ of sixty-three arthropod species. Insect molecular biology 9:393405 .

Jiggins FM, Hurst GD, Majerus ME (1998) Sex ratio distortion in Acraea encedon (Lepidoptera: Nymphalidae) is caused by a male-killing bacterium. Heredity 81:87-91.

Jiggins FM, Hurst GD, Majerus ME (2000) Sex-ratiodistorting Wolbachia causes sex-role reversal in its butterfly host. Proceedings of the Royal Society of London. Series B: Biological Sciences 267:69-73.

Jiggins FM, Hurst GD, Schulenburg JHG, Majerus ME (2001) Two male-killing Wolbachia strains coexist within a population of the butterfly Acraea encedon. Heredity 86:161166.

Kageyama D, Narita S, Imamura T, Miyanoshita A (2010) Detection and identification of Wolbachia endosymbionts from laboratory stocks of stored-product insect pests and their parasitoids. Journal of Stored Products Research 46:13-19.

Kageyama D, Nishimura G, Hoshizaki S, Ishikawa Y (2002) Feminizing Wolbachia in an insect, Ostrinia furnacalis (Lepidoptera: Crambidae). Heredity 88:444-449.

Kawai S, Matsumoto Y, Gotoh T, Noda H (2009) Transinfection of Wolbachia in planthoppers: nymphal injection of cultured Wolbachia and infection dynamics. Environmental Entomology 38:1626-1633.

Kawasaki Y, Ito M, Miura K, Kajimura H (2010) Superinfection of five Wolbachia in the alnus ambrosia beetle, Xylosandrus germanus (Blandford)(Coleoptera: Curuculionidae). Bulletin of Entomological Research 100:231239.

Kellen WR, Hoffmann DF, Kwock RA (1981)Wolbachia sp.(Rickettsiales: Rickettsiaceae) a symbiont of the almond moth, Ephestia cautella: ultrastructure and influence on host fertility. Journal of Invertebrate Pathology 37:273-283.

Klostermeyer L (1978) Eastern and western alfalfa weevils, Hypera postica (Gyllenhal): Distribution in Nebraska determined by cross-matings.(Coleoptera: Curculionidae). $\mathrm{Ph}$. D. thesis submitted to University of Nebraska-Lincoln. 
Kondo N, Shimada M, Fukatsu T (1999) High prevalence of Wolbachia in the azuki bean beetle Callosobruchus chinensis (Coleoptera, Bruchidae). Zoological Science 16:955-962.

Kondo NI, Tuda M, Toquenaga Y, Lan YC, Buranapanichpan S, Horng SB, Shimada M, Fukatsu T (2011) Wolbachia infections in world populations of bean beetles (Coleoptera: Chrysomelidae: Bruchinae) infesting cultivated and wild legumes. Zoological Science 28:501-508.

Koop JL, Zeh DW, Bonilla MM, Zeh JA (2009) Reproductive compensation favours male-killing Wolbachia in a live-bearing host. Proceedings of the Royal Society of London B: Biological Sciences 276:4021-4028.

Kremer N, Charif D, Henri H, Gavory F, Wincker P, Mavingui P, Vavre F (2012) Influence of Wolbachia on host gene expression in an obligatory symbiosis. BMC Microbiology 12: 1.

Kremer N, Voronin D, Charif D, Mavingui P, Mollereau B, Vavre F (2009) Wolbachia interferes with ferritin expression and iron metabolism in insects. PLoS Pathogens 5:e1000630.

KYEI-POKU G, Colwell D, Coghlin P, Benkel B, Floate K (2005) On the ubiquity and phylogeny of Wolbachia in lice. Molecular Ecology 14:285-294.

Lachowska D, Kajtoch $Ł$, Knutelski S (2010) Occurrence of Wolbachia in central European weevils: correlations with host systematics, ecology, and biology. Entomologia Experimentalis et Applicata 135:105-118.

Lassy CW, Karr TL (1996) Cytological analysis of fertilization and early embryonic development in incompatible crosses of Drosophila simulans. Mechanisms of Development 57:47-58.

Lo N, Casiraghi M, Salati E, Bazzocchi C, Bandi C (2002) How many Wolbachia supergroups exist? Molecular biology and evolution 19:341-346.

Lo N, Paraskevopoulos C, Bourtzis K, O'neill S, Werren J, Bordenstein S, Bandi C (2007) Taxonomic status of the intracellular bacterium Wolbachia pipientis. International Journal of Systematic and Evolutionary Microbiology 57:654657.

Lu F, Kang X, Jiang C, Lou B, Jiang M, Way MO (2013) Isolation and characterization of bacteria from midgut of the rice water weevil (Coleoptera: Curculionidae). Environmental Entomology 42:874-881.

Majerus ME, Zakharov IA (2000) Multiple causes of male-killing in a single sample of the two-spot ladybird, Adalia bipunctata (Coleoptera: Coccinellidae) from Moscow. Heredity 84:605-609.
Malloch G, Fenton B, Butcher R (2000) Molecular evidence for multiple infections of a new subgroup of Wolbachia in the European raspberry beetle Byturus tomentosus. Molecular Ecology 9:77-90.

McGraw E, Merritt D, Droller J, O'Neill S (2001)Wolbachiamediated sperm modification is dependent on the host genotype in Drosophila. Proceedings of the Royal Society of London B: Biological Sciences 268:2565-2570.

McMeniman CJ, Lane RV, Cass BN, Fong AW, Sidhu M, Wang YF, O'Neill SL (2009) Stable introduction of a lifeshortening Wolbachia infection into the mosquito Aedes aegypti. Science 323:141-144.

Merçot H, Poinsot D (2009) Infection by Wolbachia: from passengers to residents. Comptes Rendus Biologies 332:284297.

Min KT, Benzer S (1997) Wolbachia, normally a symbiont of Drosophila, can be virulent, causing degeneration and early death. Proceedings of the National Academy of Sciences 94 :10792-10796.

Ming QL, Shen JF, Cheng C, Liu CM, Feng ZJ (2015)Wolbachia Infection Dynamics in Tribolium confusum (Coleoptera: Tenebrionidae) and Their Effects on Host Mating Behavior and Reproduction. Journal of Economic Entomology 108:1408-1415.

Moran NA, McCutcheon JP, Nakabachi A (2008) Genomics and evolution of heritable bacterial symbionts. Annual Review of Genetics 42:165-190.

Moreira LA, Iturbe-Ormaetxe I, Jeffery JA, Lu G, Pyke AT, Hedges LM, Rocha BC, Hall-Mendelin S, Day A, Riegler M (2009) A Wolbachia symbiont in Aedes aegypti limits infection with dengue, Chikungunya, and Plasmodium. Cell 139:1268-1278.

Moret Y, Juchault P, Rigaud T (2001)Wolbachia endosymbiont responsible for cytoplasmic incompatibility in a terrestrial crustacean: effects in natural and foreign hosts. Heredity 86:325-332.

Narita S, Kageyama D, Nomura M, Fukatsu T (2007) Unexpected mechanism of symbiont-induced reversal of insect sex: feminizing Wolbachia continuously acts on the butterfly Eurema hecabe during larval development. Applied and Environmental Microbiology 73:4332-4341.

Negri I, Pellecchia M, Mazzoglio P, Patetta A, Alma A (2006) Feminizing Wolbachia in Zyginidia pullula (Insecta, Hemiptera), a leafhopper with an XX/X0 sex-determination system. Proceedings of the Royal Society B: Biological Sciences 273:2409-2416. 
Noda H (1987) Further studies of cytoplasmic incompatibility in local populations of Laodelphax striatellus in Japan (Homoptera: Delphacidae). Applied Entomology and Zoology 22:443-448.

Normark BB (2003) The evolution of alternative genetic systems in insects. Annual Review of Entomology 48:397-423.

O'Neill SL, Karr TL (1990) Bidirectional incompatibility between conspecific populations of Drosophila simulans. Nature 348: 178-180

Osborne SE, San Leong Y, O'Neill SL, Johnson KN (2009) Variation in antiviral protection mediated by different Wolbachia strains in Drosophila simulans. PLoS Pathogens 5:e1000656.

Pannebakker B, Schidlo N, Boskamp G, Dekker L, Dooren TV, Beukeboom L, ZwaanB, Brakefield P, Alphen JV (2005) Sexual functionality of Leptopilina clavipes (Hymenoptera: Figitidae) after reversing Wolbachia-induced parthenogenesis. Journal of Evolutionary Biology 18:1019-1028.

Paraskevopoulos C, Bordenstein SR, Wernegreen JJ, Werren JH, Bourtzis K (2006) Toward a Wolbachia multilocus sequence typing system: discrimination of Wolbachia strains present in Drosophila species. Current Microbiology 53:38895 .

Poinsot D, Charlat S, Mercot H (2003) On the mechanism of Wolbachia-induced cytoplasmic incompatibility: Confronting the models with the facts. Bioessays 25:259-265.

Rasgon JL, Gamston CE, Ren X (2006) Survival of Wolbachia pipientis in cell-free medium. Applied and Environmental Microbiology 72:6934-6937.

Rasgon JL, Scott TW (2004) Phylogenetic characterization of Wolbachia symbionts infecting Cimex lectularius L. and Oeciacus vicarius Horvath (Hemiptera: Cimicidae). Journal of Medical Entomology 41:1175-1178.

Reed KM, Werren JH (1995) Induction of paternal genome loss by the paternal-sex-ratio chromosome and cytoplasmic incompatibility bacteria (Wolbachia): A comparative study of early embryonic events. Molecular Reproduction and Development 40:408-418.

Rodriguero M, Confalonieri V, Guedes J, Lanteri A (2010) Wolbachia infection in the tribe Naupactini (Coleoptera, Curculionidae): association between thelytokous parthenogenesis and infection status. Insect Molecular Biology 19:631-640

Roehrdanz R, Levine E (2007) Wolbachia bacterial infections linked to mitochondrial DNA reproductive isolation among populations of northern corn rootworm (Coleoptera:
Chrysomelidae). Annals of the Entomological Society of America 100:522-531.

Roehrdanz R, Olson D, Bourchier R, Sears S, Cortilet A, Fauske G (2006) Mitochondrial DNA diversity and Wolbachia infection in the flea beetle Aphthona nigriscutis (Coleoptera: Chrysomelidae): an introduced biocontrol agent for leafy spurge. Biological Control 37:1-8.

Ros VI, Fleming VM, Feil EJ, Breeuwer JA (2009) How diverse is the genus Wolbachia? Multiple-gene sequencing reveals a putatively new Wolbachia supergroup recovered from spider mites (Acari: Tetranychidae). Applied and Environmental Microbiology 75:1036-43.

Rousset F, Bouchon D, Pintureau B, Juchault P, Solignac M (1992) Wolbachia endosymbionts responsible for various alterations of sexuality in arthropods. Proceedings of the Royal Society of London B: Biological Sciences 250:91-98.

Saito T, Hirai K, Way MO (2005) The rice water weevil, Lissorhoptrus oryzophilus Kuschel (Coleoptera: Curculionidae). Applied Entomology and Zoology 40:31-39.

Salunke BK, Salunkhe RC, Patole MS, Shouche YS (2010) Wolbachia and termite association: present status and future implications. Journal of Biosciences 35:171-5.

Serbus LR, Casper-Lindley C, Landmann F, Sullivan W (2008) The genetics and cell biology of Wolbachia-host interactions. Annual Review of Genetics 42:683-707.

Sheeley S, McAllister B (2009) Mobile male-killer: similar Wolbachia strains kill males of divergentDrosophila hosts. Heredity 102:286-292.

Sokolova MI, Zinkevich NS, Zakharov IA (2002) Bacteria in ovarioles of females from maleless families of ladybird beetles Adalia bipunctata L. (Coleoptera: Coccinellidae) naturally infected with Rickettsia, Wolbachia, and Spiroplasma. Journal of Invertebrate Pathology 79:72-79.

Son Y, Luckhart S, Zhang X, Lieber MJ, Lewis EE (2008) Effects and implications of antibiotic treatment on Wolbachia-infected vine weevil (Coleoptera: Curculionidae). Agricultural and Forest Entomology 10:147-155.

Starr DJ, Cline TW (2002) A host-parasite interaction rescues Drosophila oogenesis defects. Nature 418:76-79.

Stevens L, Giordano R, Fialho RF (2001) Male-killing, nematode infections, bacteriophage infection, and virulence of cytoplasmic bacteria in the genus Wolbachia. Annual Review of Ecology and Systematics. P 519-545.

Stevens L, Wade MJ (1990) Cytoplasmically inherited reproductive incompatibility in Tribolium flour beetles: the rate of spread and effect on population size. Genetics 124:367372. 
Tagami Y, Miura K (2004) Distribution and prevalence of Wolbachia in Japanese populations of Lepidoptera. Insect Molecular Biology 13:359-364.

Taylor MJ, Voronin D, Johnston KL, Ford L (2013) Wolbachia filarial interactions. Cellular Microbiology 15:520-526.

Teixeira L, Ferreira A, Ashburner M (2008) The bacterial symbiont Wolbachia induces resistance to RNA viral infections in Drosophila melanogaster. PLoS Biology 6:e1000002.

Telschow A, Hammerstein P, Werren JH (2002) The effect of Wolbachia on genetic divergence between populations: models with two-way migration. The American Naturalist 160:S54S66.

Telschow A, Hammerstein P, Werren JH, Gavrilets S (2005) The effect of Wolbachia versus genetic incompatibilities on reinforcement and speciation. Evolution 59:1607-1619.

Tram U, Ferree PM, Sullivan W (2003) Identification of Wolbachia-host interacting factors through cytological analysis. Microbes and Infection 5:999-1011.

Vala F, Breeuwer J, Sabelis M (2003) Sorting out the effects of Wolbachia, genotype and inbreeding on life-history traits of a spider mite. Experimental \& Applied Acarology 29:253-264.

Van den Hurk AF, Hall-Mendelin S, Pyke AT, Frentiu FD, McElroy K, Day A, Higgs S, O'Neill SL (2012) Impact of Wolbachia on infection with chikungunya and yellow fever viruses in the mosquito vector Aedes aegypti. PLoS neglected tropical diseases 6:e1892.

Vandekerckhove TT, Watteyne S, Willems A, Swings JG, Mertens J, Gillis M (1999) Phylogenetic analysis of the 16S rDNA of the cytoplasmic bacterium Wolbachia from the novel host Folsomia candida (Hexapoda, Collembola) and its implications for Wolbachial taxonomy. FEMS Microbiology Letters 180:279-286.

Vega FE, Benavides P, Stuart JA, O'Neill SL (2002)Wolbachia infection in the coffee berry borer (Coleoptera: Scolytidae). Annals of the Entomological Society of America 95:374-378.

Verne S, Johnson M, Bouchon D, Grandjean F (2007) Evidence for recombination between feminizing Wolbachia in the isopod genus Armadillidium. Gene 397:58-66.

Wade MJ, Stevens L (1985) Microorganism mediated reproductive isolation in flour beetles (genus Tribolium). Science 227:527-528.

Walker T, Johnson P, Moreira L, Iturbe-Ormaetxe I, Frentiu F, McMeniman C, Leong YS, Dong Y, Axford J, Kriesner P
(2011) The wMel Wolbachia strain blocks dengue and invades caged Aedes aegypti populations. Nature 476:450-453.

Weeks AR, Turelli M, Harcombe WR, Reynolds KT, Hoffmann AA (2007) From parasite to mutualist: rapid evolution of Wolbachia in natural populations of Drosophila. PLoS Biology 5:e114.

Werren JH (1997) Biology of Wolbachia. Annual Review of Entomology 42:587-609.

Werren JH, Baldo L, Clark ME (2008) Wolbachia: master manipulators of invertebrate biology. Nature Reviews Microbiology 6:741-751.

Wolfgang A, Markus R, Dimitrios N, Christian S(2009) Evidence for low-titre infections in insect symbiosis: Wolbachia in the bark beetle Pityogenes chalcographus (Coleoptera, Scolytinae). Environmental Microbiology 11:1923-1933.

Xi Z, Dobson SL (2005) Characterization of Wolbachia transfection efficiency by using microinjection of embryonic cytoplasm and embryo homogenate. Applied and Environmental Microbiology 71:3199-3204.

Xie RR, Chen XL, Hong XY (2011) Variable fitness and reproductive effects of Wolbachia infection in populations of the two-spotted spider mite Tetranychus urticae Koch in China. Applied Entomology and Zoology 46:95-102.

Yamada R, Floate KD, Riegler M, O'Neill SL (2007) Male development time influences the strength of Wolbachiainduced cytoplasmic incompatibility expression in Drosophila melanogaster. Genetics 177:801-808.

Yamada R, Iturbe-Ormaetxe I, Brownlie J, O'Neill S (2011) Functional test of the influence of Wolbachia genes on cytoplasmic incompatibility expression in Drosophila melanogaster. Insect Molecular Biology 20:75-85.

Zeh D, Zeh J, Bonilla M (2005) Wolbachia, sex ratio bias and apparent male killing in the harlequin beetle riding pseudoscorpion. Heredity 95:41-49.

Zhang YK, Ding XL, Rong X, Hong XY (2015) How do hosts react to endosymbionts? A new insight into the molecular mechanisms underlying the Wolbachia-host association. Insect Molecular Biology 24:1-12.

Zhao DX, Zhang XF, Chen DS, Zhang YK, Hong XY (2013) Wolbachia-host interactions: host mating patterns affect Wolbachia density dynamics. PloS one 8:e66373.

Zheng Y, Wang JL, Liu C, Wang CP, Walker T, Wang YF (2011) Differentially expressed profiles in the larval testes of Wolbachia infected and uninfected Drosophila. BMC Genomics 12: 595 
Zhou W, Rousset F, O'Neill S (1998) Phylogeny and PCRbased classification of Wolbachia strains using wsp gene sequences. Proceedings of the Royal Society of London B: Biological Sciences 265:509-515 